University of Nebraska - Lincoln

DigitalCommons@University of Nebraska - Lincoln

PreColumbian Textile Conference VIII /

Jornadas de Textiles PreColombinos VIII (2019)

Centre for Textile Research

$6-2020$

\title{
Hidden in plain sight. How 'disturbing' features found within two Peruvian textile fragments have turned into a 'significant guide' for conservation
}

Griet Kockelkoren

Emma Damen

Follow this and additional works at: https://digitalcommons.unl.edu/pctviii

Part of the Art and Materials Conservation Commons, Fiber, Textile, and Weaving Arts Commons, Indigenous Studies Commons, Latin American Languages and Societies Commons, Museum Studies Commons, and the Other History of Art, Architecture, and Archaeology Commons

This Article is brought to you for free and open access by the Centre for Textile Research at DigitalCommons@University of Nebraska - Lincoln. It has been accepted for inclusion in PreColumbian Textile Conference VIII / Jornadas de Textiles PreColombinos VIII (2019) by an authorized administrator of DigitalCommons@University of Nebraska - Lincoln. 


\title{
Hidden in plain sight. How 'disturbing' features found within two Peruvian textile fragments have turned into a 'significant guide' for conservation
}

\author{
Griet Kockelkoren* \& Emma Damen ${ }^{\dagger}$ \\ * Textile conservator and head of the Conservation Studio of Historical and Contemporary Textiles, Costumes and \\ Accessories of the Royal Institute for Cultural Heritage (KIK-IRPA) in Brussels \\ † Textile conservator at the Royal Institute for Cultural Heritage (KIK-IRPA) in Brussels
}

\section{Resumé}

Préserver non seulement 'l'objet matériel', mais préserver également les valeurs intrinsèques d'un objet n'est pas un nouveau concept dans la pratique de la conservation-restauration actuelle. Le défi de cette approche consiste à regarder au-delà de ce qui est visible à l'œil nu et à déterminer les traces de signification qui sont présentes dans l'objet. Au début d'une recherche ou une conservation, les aspects sont inconnues et parfois bien déguisés. Les traces essentielles peuvent être très difficiles à évaluer et à valoriser, en particulier avec des objets textiles ayant servi à une ou plusieurs fins pratiques au cours de leur vie avant de faire partie d'une collection patrimoniale.

A travers de deux cas pratiques, cet article décrit l'application pratique de l'approche choisie pour comprendre et dévoiler les aspects que nous voulions vraiment valoriser et préserver pour le futur en raison de leur signification et comment ils se sont avérés déterminants dans le choix de conservation.

Mots-clés : signification, valeur immatériel, risques, biographie matérielle, fragment textile péruvien, conservation de textile, recherche de textile, musée d'Art \& Histoire Bruxelles

\begin{abstract}
Preserving not only the 'material object', but preserving the intrinsic values of an object is not a novel concept within the contemporary conservation practice. The challenge of this approach lies in looking beyond what is visible to the naked eye and in determining the unknown and sometimes well disguised aspects and traces of 'significance' that are present within the object. Trace elements can be very difficult to assess and to value, especially within textile objects that have served one or more practical purposes during their 'active life', before becoming part of a heritage collection. Via two practical cases, this article describes the practical application of the chosen approach to understand and unveil those aspects we really wanted to value and preserve due to their 'significance' and how they turned out to be instrumental in the conservation choices.
\end{abstract}

Keywords: significance, intangible value, risks, active life, material biography, Peruvian textile fragment, conservation, textile conservation, textile research, Royal Institute for cultural heritage, Art \& History Museum Brussels.

\section{Resumen}

Preservar no solamente el 'objeto material', sino sus valores intrínsecos no constituye un concepto novedoso dentro de las prácticas de conservación 'contemporánea'. El reto de esta pauta queda en ver más allá de los que es visible al ojo y en determinar los aspectos desconocidos y, a veces, ocultos y las huellas de ‘significado’ presentes dentro del objeto. Al trazar estos elementos, puede ser difícil medirlos y valorarlos, especialmente para de objetos textiles que han tenido una función pragmática, o más de una, durante su 'vida activa', antes de entra a formar parte de una colección patrimonial. A través de

DOI: 10.32873/unl.dc.zea.1216

Published in PreColumbian Textile Conference VIII / Jornadas de Textiles PreColombinos VIII, ed. Lena Bjerregaard and Ann Peters

(Lincoln, NE: Zea Books, 2020). https://digitalcommons.unl.edu/zeabook/ 
dos casos particulares, este artículo describe la aplicación en la práctica de este método que se ha escogido para entender y hacer visible aquellos aspectos que hemos querido valorar y preservar, debido a su 'significado', y ver cómo han resultado ser instrumentales en las opciones del proceso de conservación.

Palabras claves: significado, valor intangible, riesgos, vida activa, material biográfico, fragmento textil peruano, conservación, conservación textil, investigación textil, Instituto Real para el patrimonio cultural, Museo de Arte \& Historia de Bruselas.

In preparation of the temporary exhibition "INCA dress code" (23/11/2018-21/04/2019) at the Art \& History Museum in Brussels, two Peruvian textile fragments from the collection of the museum were researched and treated at the textile conservation studio of the Royal Institute for Cultural Heritage (KIK-IRPA). The aim was to preserve not only the 'material object', but also its intrinsic value(s). The challenge lies in looking beyond what is visible to the naked eye and in determining the unknown and sometimes well disguised aspects and traces that are present within the object. This article describes the chosen approach to understand and unveil those aspects we really wanted to 'value' and preserve due to their 'significance' and how they turned out to be instrumental in the conservation choices.

\section{What should be preserved?}

There is no discussion concerning the importance of preserving heritage. It seems straightforward enough, but as a conservator confronted with an object, a much more pressing and challenging question is, what it is about the object that we want to preserve? Do we want to preserve as much material of the object as it is now, in its present state? Do we just want to preserve the first and most original state of the object and remove all later add-ons? Do we want to focus on the traces of use? Or is there something else?

Many objects that came to the textile conservation studio of the Royal Institute for Cultural Heritage (KIK-IRPA) in Brussels have raised these types of questions. When looking at objects, in most cases it actually comes down to, how we can make sure that we are preserving all the significant aspects of the object here before us and that we do not remove or take away anything that might have cultural-historical value, social value or value that tells something about the use. ${ }^{1}$

The consideration of these values is sometimes referred to as value-assessment ${ }^{2}$, but some colleagues feel that the word value is too closely associated in most of our minds with money, therefore the word 'significance' is often preferred.

Preserving not only the 'material object' but rather 'preserving what is valued'3 is not a new concept in 'contemporary' conservation practice. However, it does require a certain mind-shift and makes you think about the meaning of preservation, the meaning of use, the intrinsic meaning of an object and the meaning of the 'integrity' of the object. Taking all these into account in the conservation-approach, brings some uncertainties that need to be tackled before any hands-on conservation-action can be undertaken and often it necessitates more insights than can be found in just one person or specialism.

This concept aims to go further than preserving or actively conserving the physical integrity of the object. It also respects and takes into account its conceptual integrity and therefore also the beliefs and uses that the originator attributed to a specific object. ${ }^{4}$

This being said, it is also important to take into account the fact that heritage objects can have had more than one use(r) in, at times, very different cultures and periods during history. All these traces of use imprinted in the material biography, are considered to be of significance.

1. Significance 2.o. https://www.arts.gov.au/what-we-do/museums-libraries-and-galleries/significance-20 last consulted on the 3 th of October 2019.

2. See for example: Michalski, Stefan, Pedersoli Jr., José Luiz (2016) The ABC Method: a risk management approach to the preservation of cultural heritage, CCI, ICCROM; Brokerhof, A.W., Bülow, Anna E. (2016) The QuiskScan - a quick risk assessment scan to identify value and hazards in collection. Journal of the Institute of Conservation, Volume 39, pp 18-28; Waller, R.R. (2003) Cultural Property Risk Analysis Model: Development and Application to Preventive Conservation at the Canadian Museum of Nature, Göteborg Studies in Conservation 13, Göteborg: Göteborg Acta Universitatis Gothoburgensis; Ashley-Smith, Jonathan (1999) Risk Assessment for Object Conservation, Oxford: Butterworth-Heinemann.

3. Clavir, Miriam (2002) Preserving What is Valued. Museums, Conservation, and First Nations, UBC Press Vancouver.

4. For some objects and cultures, this could mean that both the continued use (intangible) and the material preservation (tangible) are (as) important within the preservation concept. Think for example of various ethnographic objects. However, this article only focusses on the preservation of the material integrity as well as the preservation of the material traces of previous use(s) found, their interpretation, the understanding of these traces within/on the objects in the case study. See Miriam Clavir, 2002. 
This approach goes well beyond what is usually stated in the various 'codes of ethics' that are omnipresent in the modern day conservation practice. These 'codes' represent guidelines rather than rules, to cater to the fact that every case and object is very different. But this also means they often remain very generic and that there is not one 'code' that really covers every aspect. ${ }^{5}$ To interpret them too literally could even pose a risk to the objects treated ${ }^{6}$. Therefore the challenging but also intriguing part is to be able to interpret and apply these guidelines ${ }^{7}$ and tailor them to specific objects in relation to their unique context and 'use'8.

Through these codes or guiding concepts such as minimal intervention, retreatability, reversibility, recognizability of any new added material during conservation, the field still aims to create unity and certain 'standards' within the conservation practice and process. But as most things in conservation and heritage science, you can never approach them as being solely black and white, but many more considerations are needed. For example, conservation treatments often start with cleaning the surface of objects. But cleaning inevitably implies removing something. This means cleaning can never be reversible. This is just one example, that illustrates that it is in all cases very important to very carefully consider every step of the treatment for each unique object by weighing the benefits versus the risks of loss, now and in the future, all starting with the question 'to clean or not to clean?'. As clearly stated by Jonathan Ashley Smith at the ICOM-CC conference in 2017 , the one aim of ethical guidance, is to require the conservator to consider all available options. But this unavoidably means maximum understanding of the object in its broadest possible sense.

So in addition to the well-known guidelines, we should recognize the need to aim within our conservation concepts to at least carefully consider the preservation of every aspect present within the material biography of an object, that can give more information about the object and its context. This is especially the case for objects such as historic ones, partially or fully constructed out of textiles, that served one or more practical purposes during their 'active life'. In addition, we want to keep these features researchable in the future so they can still be examined and maybe even be more correctly understood and therefore 're-valued' in the future when new methods, techniques or insights might become available.

\section{To look beyond the naked eye}

The challenge in 'unravelling' this material biography is to try and look beyond what the naked eye can see and to really understand what it is we are seeing. Not an easy task, but a very interesting one. With all the scientific knowledge and research-tools we have at the moment, there is no reason to let this aim, of understanding the unknown, scare us or hold us back. To recognize and understand is our first aim, but to be able to interpret and also to distinguish between traces of 'value' and traces of undesired change that could be referred to as damage is the following ste ${ }^{10}$. But there is never, or rarely, one simple answer to what appears to be such a simple question. Therefore it is so very important and often instrumental in our conservation-decision-making-process, to closely collaborate, communicate and create understanding between art historians, curators, conservations-scientists and conservators ${ }^{11}$.

As caretakers of objects and all that this or they may mean, we should encourage open discussion and broader understanding. We all try to achieve this in our own way, but during the actual practical application, this process often proves to be full of obstacles. We need to be aware and keep in mind that for example the curator-object relationship is rather different from the conservator-object relationship and different again from the conservation-scientist-object relationship. Each actor has different perceptions and experiences, but when combined, they complement one another immensely and it is through understanding each other, that we can start to understand the object more fully. And this kind of understanding is often very instrumental in the

5. Ashley-Smith, Jonathan (2017) 'A role for bespoke codes of ethics', Pre-prints of the ICOM-CC $18^{\text {th }}$ Triennial Conference Theory and History of Conservation. Copenhagen.

6. Ashley-Smith, 2017.

7. See for example: ICOM-code of ethics, the ethical guidelines of AIC, ECCO and many more.

8. See Figure 1: Triangle of collection management in: A. W. Brokerhof, 'Collection Risk Management - The Next Frontier', Presented at the Canadian Museums Association Cultural Property Protection Conference. Ottawa, 2006. p 2.

9. During the time before they became part of a museum's collection and before they were given a 'heritage' status.

10. S. Stansiforth (1994) 'Group report What are Appropriate Strategies to Evaluate Change and to Sustain Cultural Heritage', Report of the Dahlem workshop Durability and Change on 6-11 Dec 1992 in Berlin. New York, pp. 218-223; J. Ashley-Smith (1995) 'Definitions of Damage', Text of a talk given in the session 'when conservator and collections meet' at the Annual Meeting of the Association of Art Historians, Londen, April 7-8, 1995, not published. https://cool.conservation-us.org/byauth/ashley-smith/damage.html last consulted on the 3th of October 2019. 11. Depending on the case, it goes without saying that more input can be required than mentioned, for example of anthropologists and related communities. 


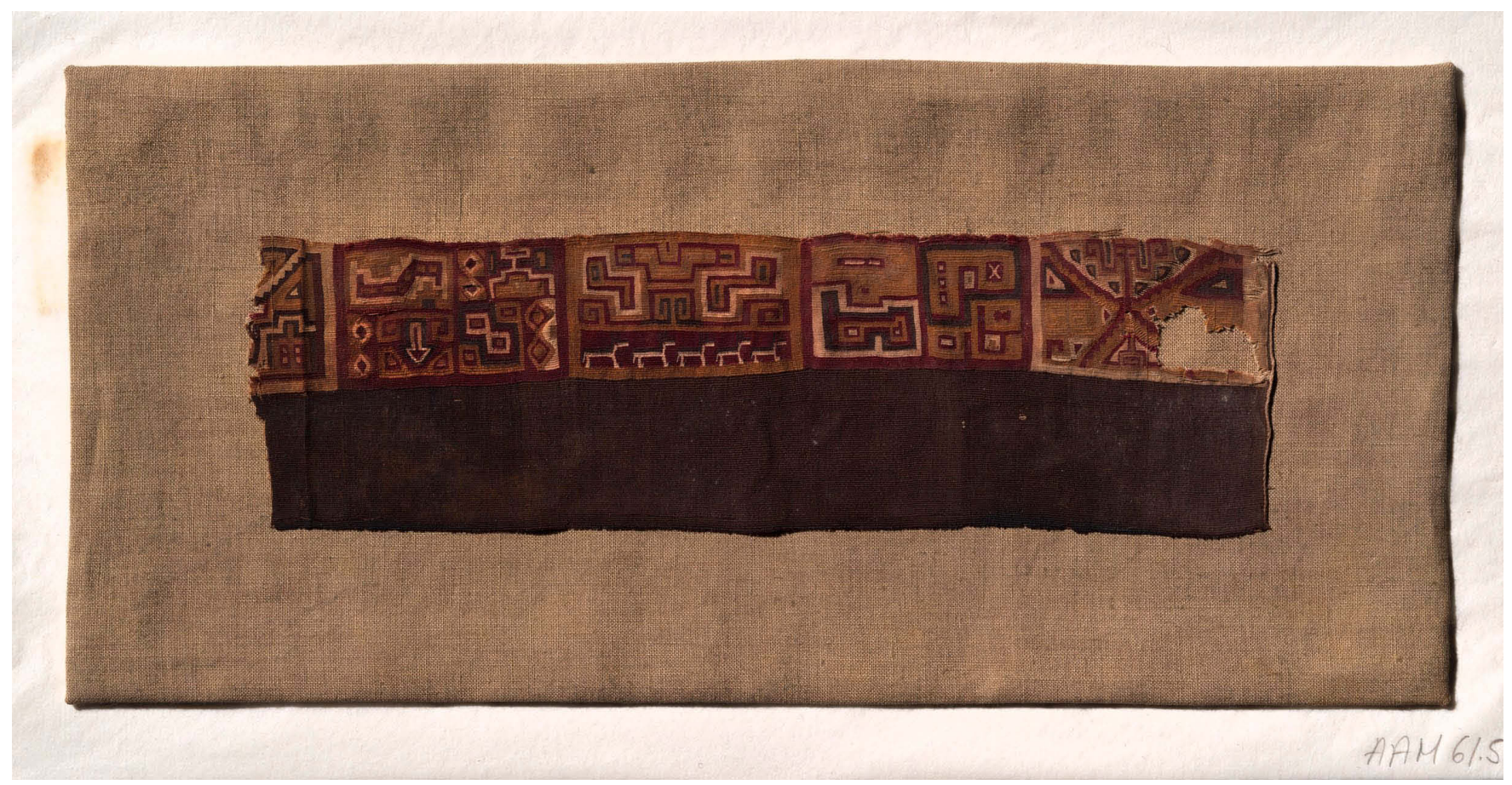

Figure 1: AAM61.5 before conservation treatment in 2017 (dimensions $24 \times 7 \mathrm{~cm}$ ) (C) KIK-IRPA x120596

conservation choices and treatments that follow. They are a guide to mitigate the risk(s) of loss of significance that could occur due to conservation treatment.

The two case studies of the conservation of Peruvian textiles, as described here below, proved vivid examples of this.

\section{Case-study: The conservation of two Peruvian textile fragments}

In preparation of the "Inca dress code" exhibition (23/11/2018-21/04/2019) at the Royal Art and History museum in Brussels, the Royal Institute for Cultural Heritage carried out the research and conservation treatment of two Peruvian textile fragments that were presented during this exhibition and that are both an example of 'significance hidden in plain sight'.

\section{The significant value of a "disturbing" haze}

The first fragment that was treated at the textile conservation studio of the KIK-IRPA can be dated between 1450$1532^{12}$. This exquisite textile fragment, that can be seen in figure 1, was woven in an extremely fine tapestry technique in vicuña wool (weft) and cotton (warp) ${ }^{13}$ with a density of 25-28 warp threads to 164 weft threads per $\mathrm{cm}$. In collaboration with Christophe Moulherat of the "Musée du Quai Branly" in Paris, several images were taken (in Brussels) with a Hirox-microscope that illustrates the density of this textile fragment very well, as can be seen in figure 2 .

Before this textile fragment entered the textile conservation studio in 2018, it had already undergone a very general conservation treatment in the 1980's when the fragment was mounted and consolidated on a beige support fabric with the result that the backside, except for a small cut out peephole in the support fabric, could not be consulted.

One of the most pressing conservation issues at the moment of entry in the studio in 2018 , was that, in several places at the front side of the textile fragment, a white disturbing haze could be seen giving the textile a strange appearance. Naturally, we did not want to start the cleaning process without knowing what we were confronted with, so, the primary focus of the preliminary research was to determine the nature and origin of this strange white substance.

The first assumption was that this might be mold but, after a negative ARA-kit test ${ }^{14}$, this assumption could be

12. Information provided by Serge Lemaitre, curator and collection caretaker of the Royal Museum of Art and History in Brussels. 13. Ina Vanden Berghe, conservation scientist at the KIK-IRPA, carried out a fiber identification 14. DG-18 ARA- Kit from Bio Trading 


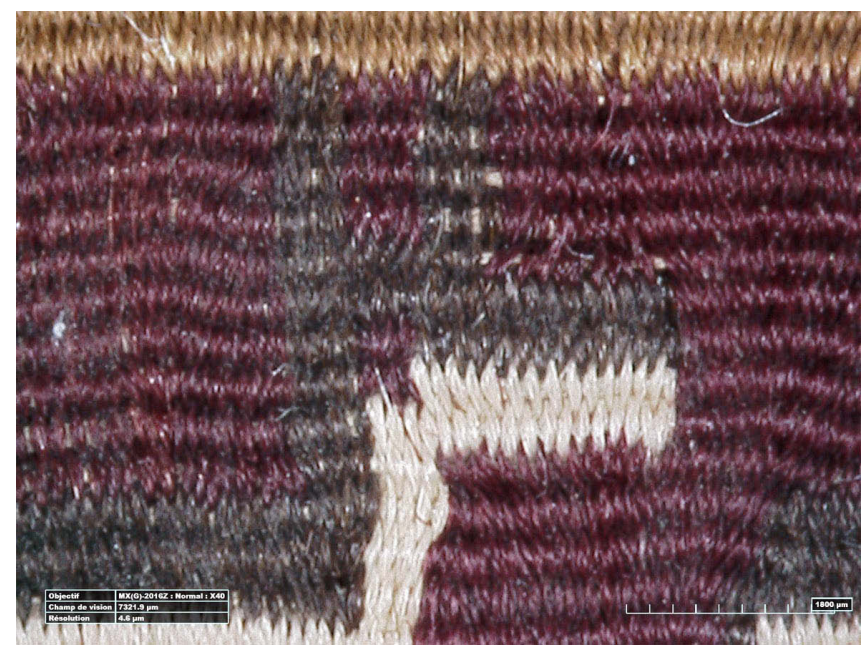

Figure 2: Detail AAM61.5 with Hirox-microscope (C) C. Moulherat

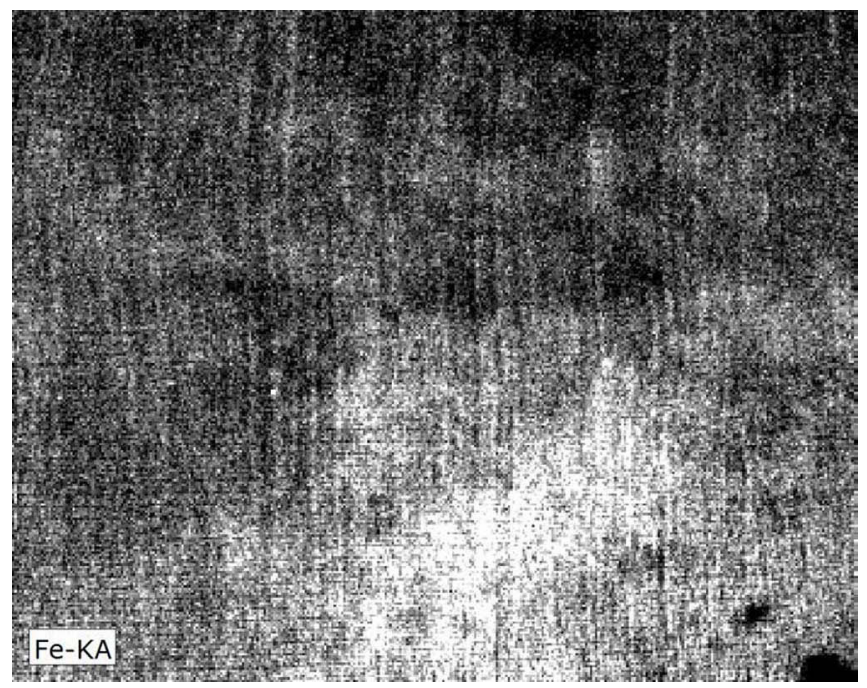

Figure 3: MA-XRF Fe \& KA mapping (C) KIK-IRPA

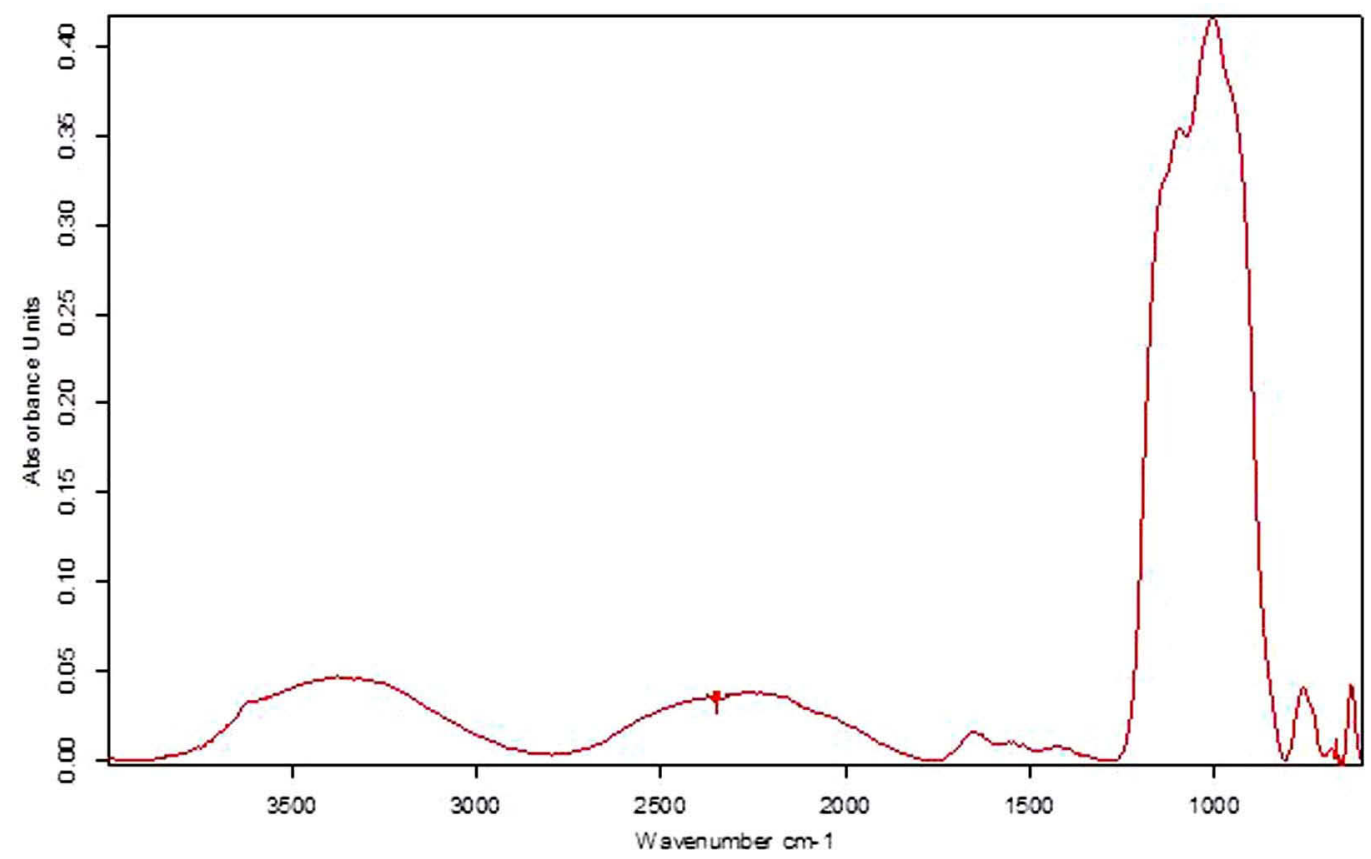

Figure 4: FTIR analyze (C) KIK-IRPA

discarded. Marina Van Bos, conservation scientist in our laboratory department, performed further analysis on the white haze in order to determine its nature.

The first analysis was conducted with the non-invasive technique of MA-XRF. This technique allows analyzing the chemical elements present on and in the textile surface without taking any samples. A small area that contained the white haze was analyzed with the Bruker M6 Jetstream. ${ }^{15}$
As can be seen in figure 3, results show a higher concentration of iron in these areas than in other parts of the textile fragment.

Additional Fourier Transform Infrared Spectroscopy was carried out, using the Vertex 70 spectrometer linked with the Hyperion 3000 - Bruker microscope. As can be seen in figure 4 , the results show an absorption from silicon-oxygen. In combination with the results of the MA-XRF, there 


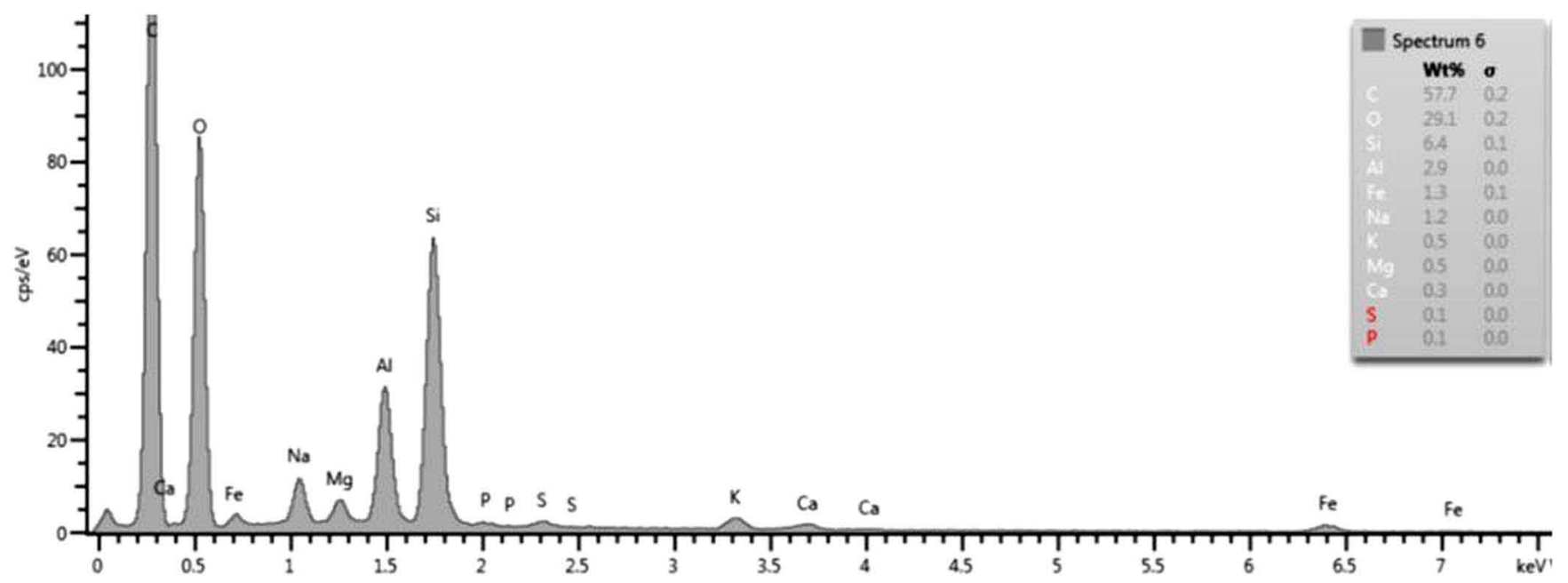

Figure 5: MEB-EDX spectrum of AAM.61.5 (C) KIK-IRPA

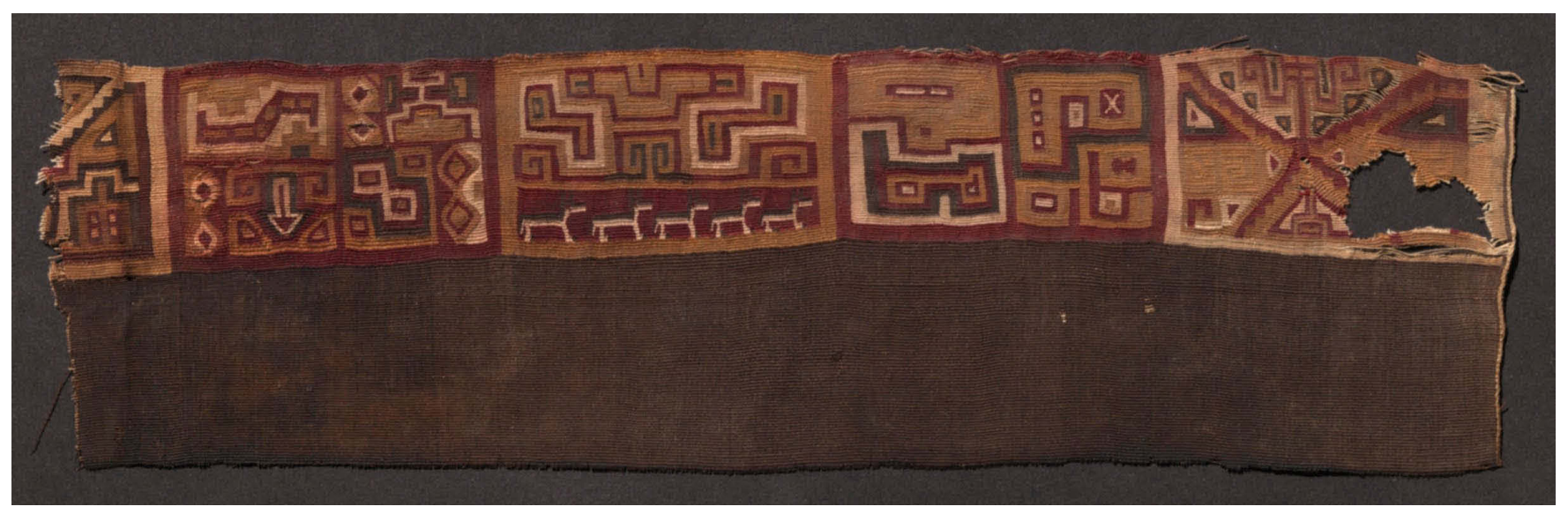

Figure 6: AAM61.5 after conservation treatment (dimensions 24 x 7cm) (C) KIK-IRPA x125816

was the assumption that the white haze might be a kind of soil, like clay. To confirm this assumption, a third and last analysis was carried out by using MEB-EDX analyses.

This was carried out using a Zeiss EVO LS15 and a detector of Oxford Instruments. The EDX spectrum presented in figure 5 shows the presence of oxygen, iron, aluminum, silicon and iron. The presence of these elements confirms the assumption that the white residue could be clay. A clay that probably can be traced back to the clay left from the environment where the object was found during its excavation. Therefore, this clay can be seen as a part of the storytelling of the history of the object, as a part of the "previous life" of the fragment. Hence, it is of 'significance'.

Before the results of these analyses, the first impulse was to remove the haze, but, after this better understanding, removing it would be an important loss of significant value. And although we are not exactly sure where this clay comes from, we want to keep the clay in order to make eventual future research on it possible. An additional factor that could support such a decision for these types of archeological objects and collections, is that when the provenance is uncertain or unclear, holding on to elements like these could be of great value in their future research.

Since a wet cleaning is an irreversible treatment that could remove significant value, we asked ourselves the challenging question “to clean or not to clean?". For this case study we decided to do a relaxation of the fibers in order to give more flexibility to the weaving structure by using humidity. This also improved the visual aspects of the fragment, but in no way did it remove the clay-matter. So the treatment was carried out in such a way that all the significant features of the fragment could be preserved and consulted in the future.

Because of the amazing craftmanship and the incredible weaving density of this small textile fragment, we found it most important that the entire backside of the textile could 


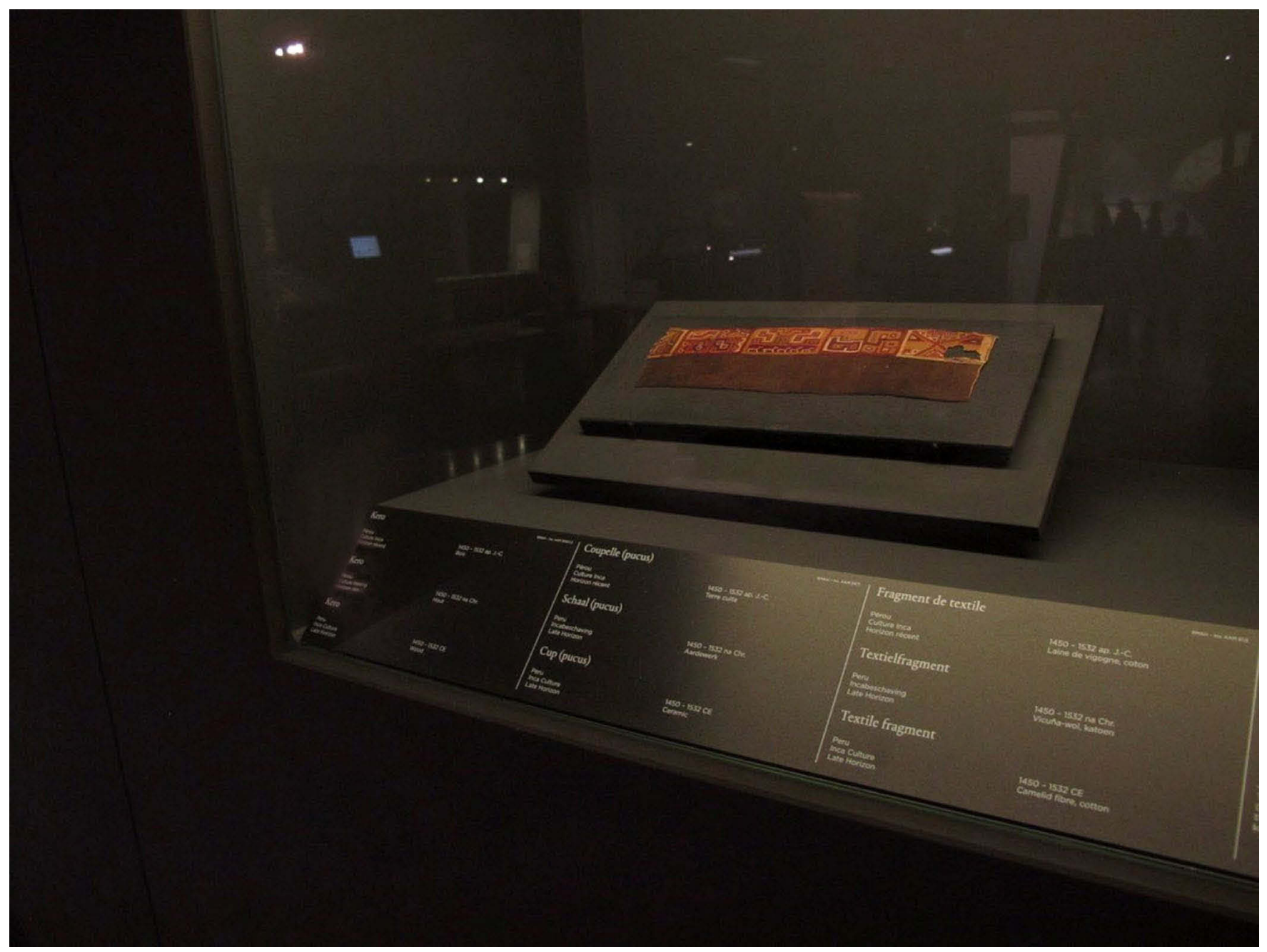

Figure 7: Textile fragment during exhibition INCA dress code (c) Emma Damen

be consulted from now on and for future research. That is why we decided to remove the beige support fabric and make a custom preservation-, transport- and presentation mount in order to minimize the handling of the fragment.

The final result can be seen in figure 6 and a picture of the object during exhibition in figure 7. The relaxation of the fibers resulted in brighter colors, a more vivid appearance and a general improved lecture of the geometrical figures in the fragment. The white haze is minimized, but certainly not entirely removed, in order to ensure the preservation of as much of the intangible values of this fragment as possible. The conservation treatment did not only contribute to the durable preservation, it also ensured keeping all material aspects of significance within of the object researchable for the future. Thanks to its new mount, it also ensures that further research can be carried out with an easier access for the researcher and in a safer way for the object.

\section{The significant value of "disturbing" stitches}

The second fragment, that was treated in the textile conservation studio of KIK-IRPA, in preparation of the same exhibition, can be dated at the end of the $16^{\text {th }}$ century. ${ }^{16}$ It is also woven in a tapestry technique with cotton applied for the warp and vicuña wool for the weft. ${ }^{17}$ Here, it was not a white haze that caught the eye and drew attention away from the object itself, but an old darning on the upper side of the fragment, together with additional sewing stitches all around the border of the textile fragment, as can be seen in figures 8 and 9 . 


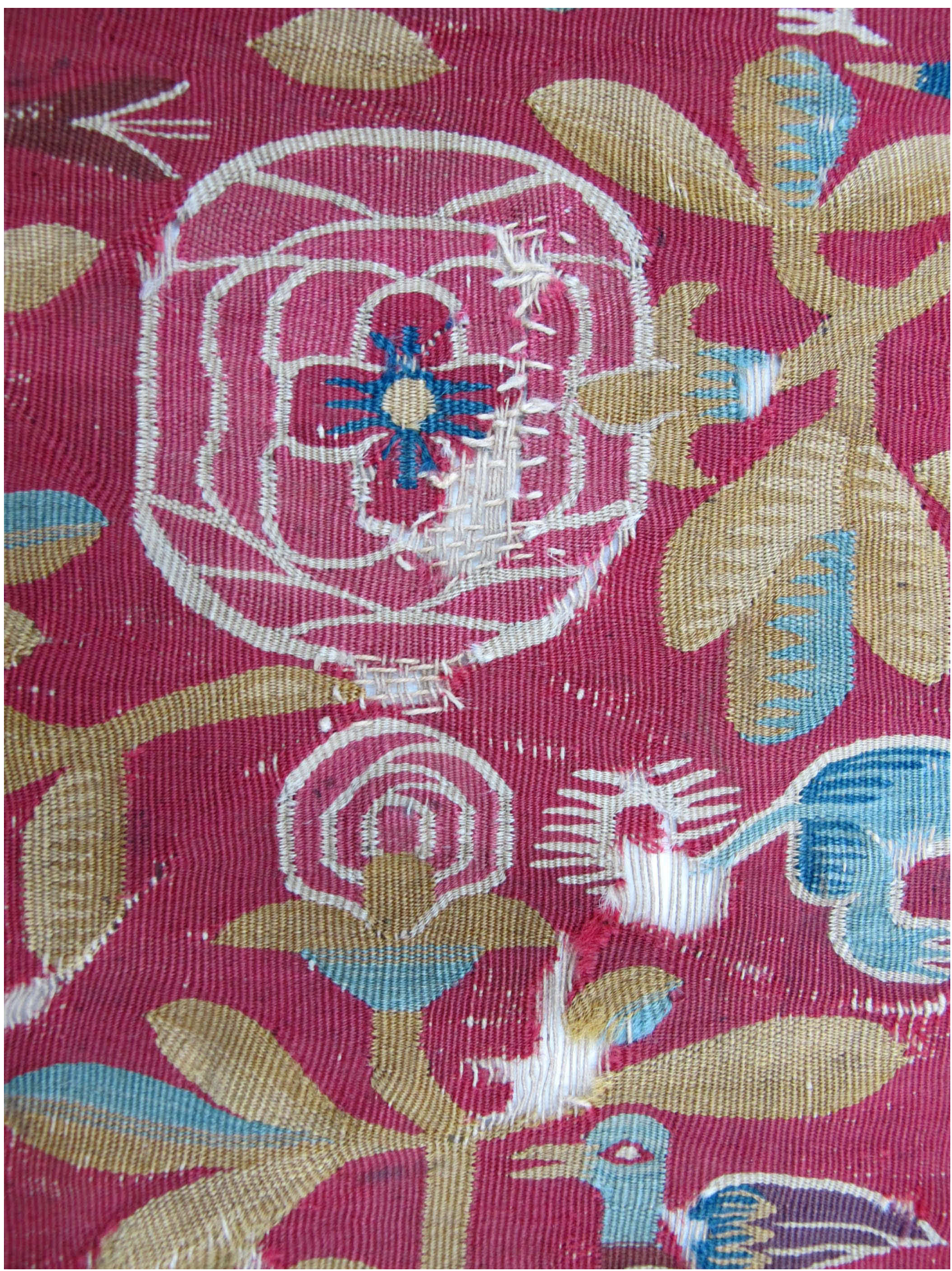

Figure 8: Detail old darning textile fragment 737 @ KIK-IRPA 


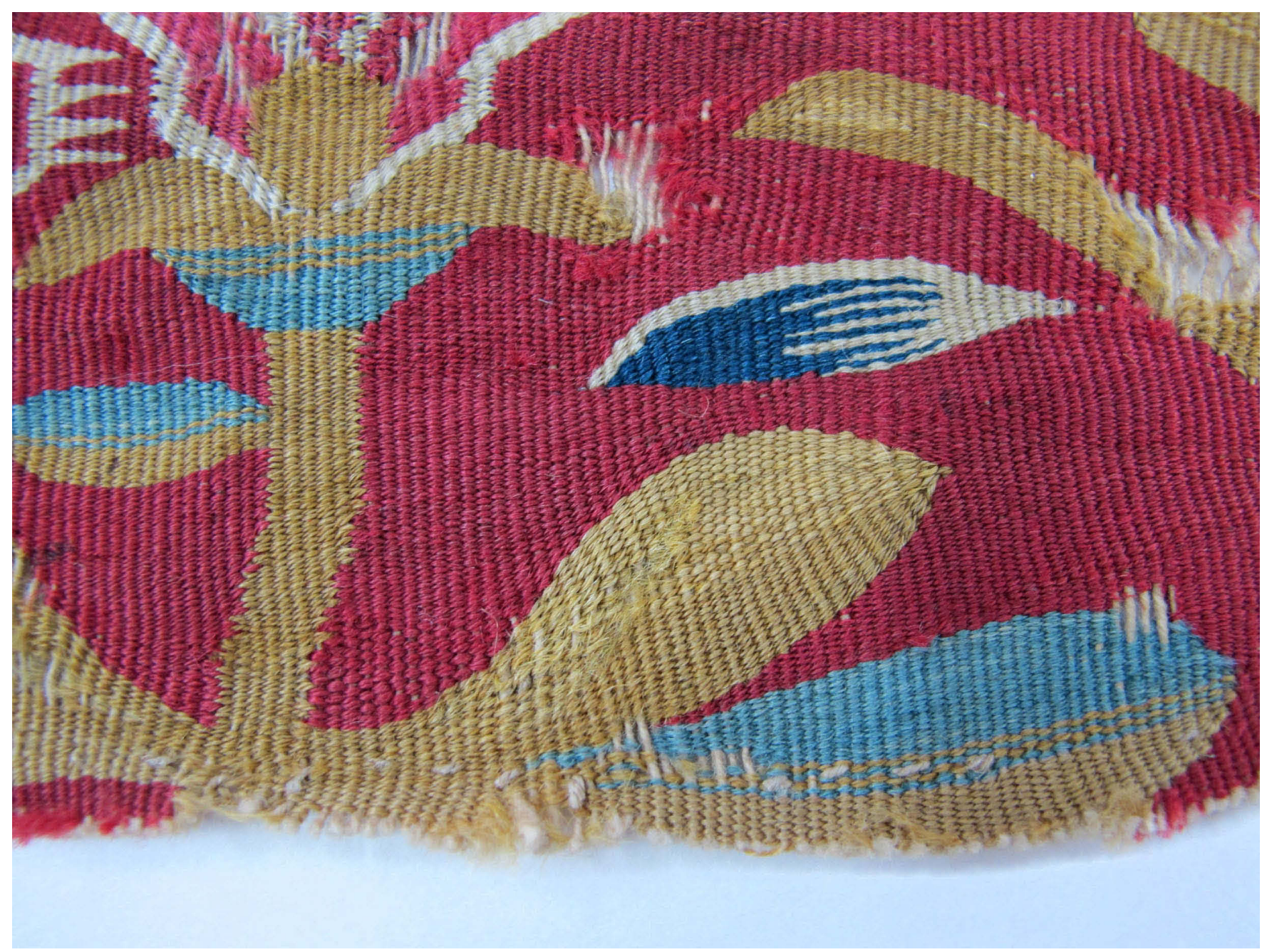

Figure 9: Detail old sewing stitches all around the border (C) KIK-IRPA

For the preparation of the exhibition, the question of the museum was to remove this somewhat disturbing darning, but, when we took a closer look, it could be determined that this darning was carried out when the backside of the fragment was not accessible. It gave us a first indication that this textile fragment was possibly used as a pillow cover or as another functional object during a part of its active life. The manner in which the stitches where applied shows that the person that applied the stitching had no access to the backside of the textile and therefore could only work from the front of the object. In addition, the sewing stitches that can be found all around the border of the textile fragment, could confirm this assumption. So again, a part of the intangible value could be lost if the darning and stitches would be removed. Because of this and because these later added stitches do not create any tension in the object, we decided to leave them in place, but to harmonize them so that these somehow "disturbing features" would be less visible, yet still consultable for the future. The chosen conservation treatment would have to support the weaker areas at the same time. Therefore, it was decided to consolidate the fragment as a whole.

The fact that the backside would no longer be easily consultable after treatment seems to point to an opposite logic from the one followed for the first, smaller textile fragment. But here, in consultation with the curator and collection caretaker, guided by the specific needs of this object, it was decided that, in this case, it was more important to conserve the weaker areas in order to preserve it as durably as possible for the future. As a compromise, we documented the backside elaborately with photographs in high resolution 


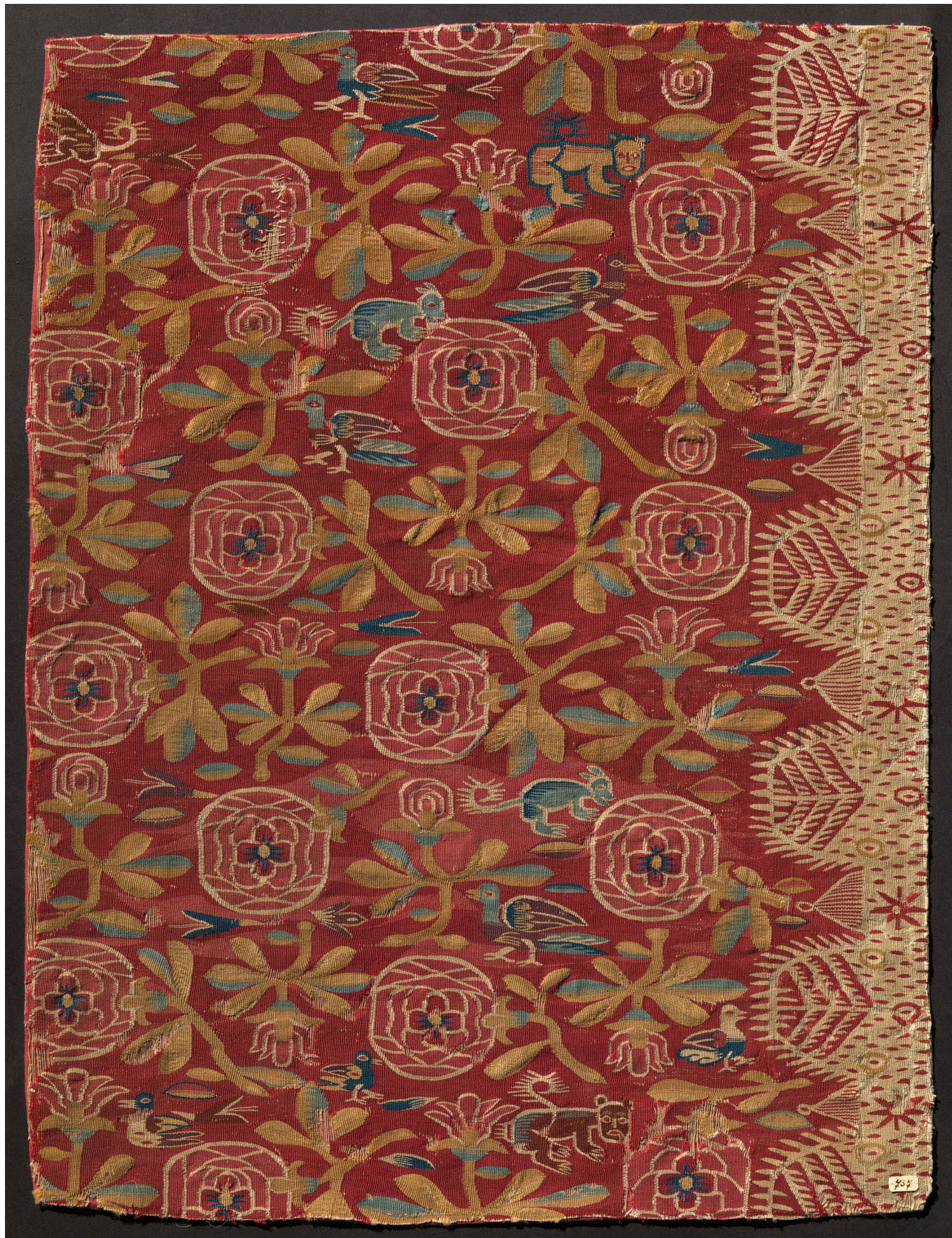

Figure 10: 737 after conservation (dimensions : 60 x 45 cm) (C) KIK-IRPA x125811 


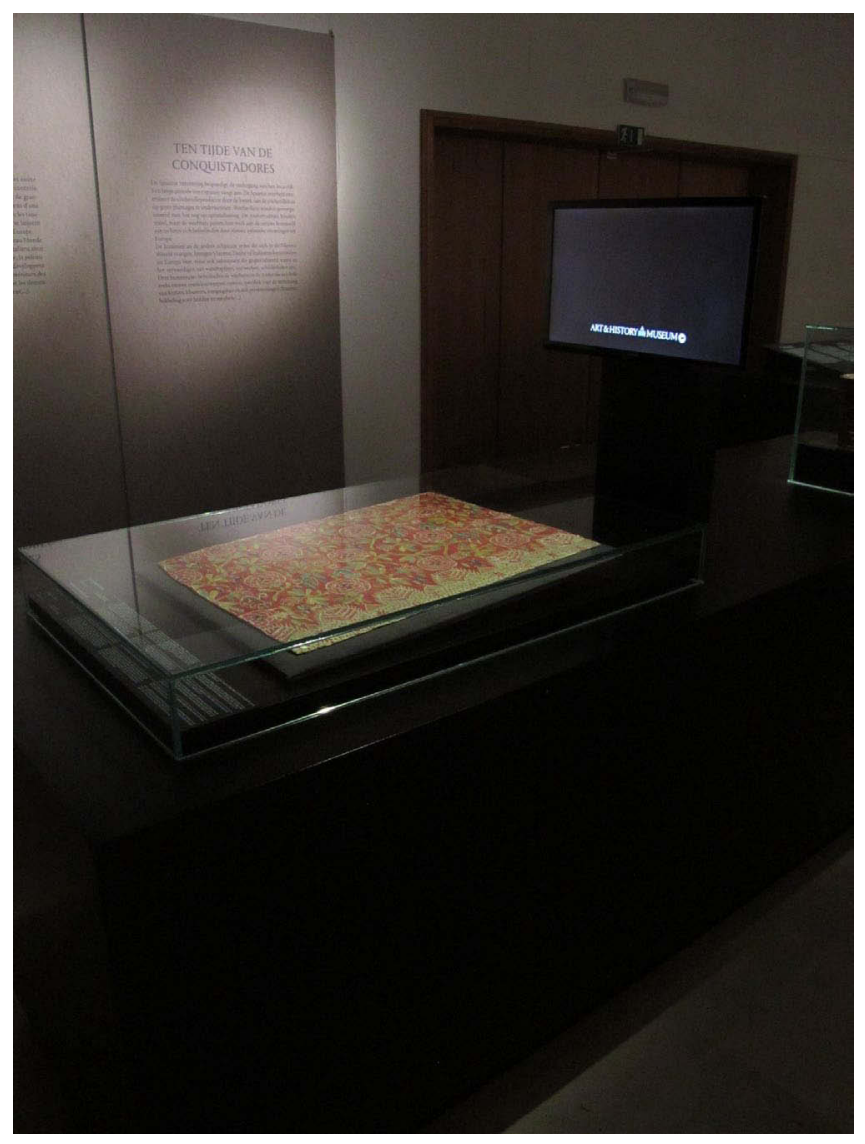

Figure 11: 737 during exhibition (c) Emma Damen

so future research can still be carried out without actually touching the object.

To harmonize the lacunas on each part of the textile fragment, we decided to work with a support fabric that consisted of two different colors. Consolidation stitches where used to attach the fragment to the support fabric. For the presentation and preservation mount we used the same method as the one applied on the first textile fragment. Together with the preservation box, there is no need to handle the object directly, which will be a great help in preserving all possible tangible and intangible features of the object in a durable way for the future.

\section{Conclusion}

These two case studies illustrate vividly, how unknown, seemingly disturbing and at first sight unwanted aspects in an object can turn out to be of significance and something really worth holding on to in conservation practice, despite all the facts that ruled against them. By looking at objects from a different angle, as these cases certainly show, great 'value' can even be found in 'dirt'. It all depends...

In order to ensure that we are not losing, or unknowingly and unwillingly removing 'valuable heritage' for future generations, it is more than worthwhile to consider every feature of an object, no matter how small, ugly or insignificant they may seem at a first glance.

\section{Acknowledgements}

We would like to give special thanks to our colleagues and in-house conservation scientists. Dr. Ina Vanden Berghe and Dr. Marina Van Bos with the assistance of Maaike Vandorpe. Dr. Mathieu Boudin with the assistance of Tess Van den Brande. The result of their research was invaluable at determining the conservation treatment for these two cases.

Thanks to Dr. Serge Lemaitre from the Art \& History Museum in Brussels for entrusting us with these extraordinary objects from his collection, for sharing their story and context so passionately, for inviting us to present our thoughts and experiences and to write this article. We would also like to thank everyone else who made this publication possible in any way or form.

Dr. Christophe Moulherat of the museum of Quai Branley also found his way to our conservation studio via Serge Lemaitre and via his approach he literally made us see the object in a whole new light.

Michelle De Brueker who shared her thoughts and experiences with us from within the conservation studio of the KIKIRPA.

And last but not least, Piet Veldeman and Karen Bonne for their razor-sharp insights at the development of this article. 